\title{
Influence of Mixed Alkali on Fixation of Deep Shade on Single Jersey Cotton Fabrics with Reactive Dyes
}

\author{
Muhammad Abdur Rahman Bhuiyan*, Md. Abdus Shahid, Md. Abdul Hannan, Md. Abdullahil Kafi \\ Department of Textile Engineering, Dhaka University of Engineering and Technology (DUET),
}

Gazipur-1700, Bangladesh

\begin{abstract}
This paper presents the influence of mixed alkali (soda ash and sodium hydroxide) on fixation of deep shades (8\%, 7.6\% and $7.2 \%$ ) of Novacron super black $G$ and Cottofix black $B$ reactive dyes. The experiment explored the possibility of using the mixed alkali as a fixing agent for deep shade in the dyeing of single jersey cotton fabric instead of soda ash only. By using the proper amount of mixed alkali during dyeing, the dyed fabrics showed very good to excellent fastness properties and the process cost was reduced due to high exhaustion and fixation of dye molecule. The results showed that the reactivity of reactive dye was increased, $10 \%$ dyes was saved and the fastness of rubbing and washing were improved for each shade.
\end{abstract}

Keywords: Mixed Alkali, Cellulose, Hydrolysis, Reactive Dye, Deep Shade and Knit Fabrics

\section{Introduction}

A reactive dye is a colored compound which has a suitable group enable of forming a covalent bond between a carbon atom of a hydroxy or an amino group of the substrate ${ }^{[1]}$. This dye consists with chromophoric grouping - contributing the color, reactive system enabling the dye to react with the hydroxyl groups in cellulose, a bridging group that links the reactive system to the chromophore and one or more solubilising groups

${ }^{[2]}$. Reactive groups are the responsible for the fixation on alkaline condition. The role of the alkali is to cause acidic dissociation of some of the hydroxyl groups in the cellulose, and it is the cellulosate ion (Cell- $\mathrm{O}^{-}$) that reacts with the dye ${ }^{[3,4]}$. The hydroxyl groups in cellulose are weakly acidic and absorption of hydroxide ions causes some dissociation, forming cellulosate ions. It is these that react with the dye by nucleophilic addition or substitution. In general, the lower the reactivity of the reactive groups of the dye towards the alkaline cellulose, the higher the final dyeing temperature and the higher the final $\mathrm{pH}$ of the dyebath. Unfortunately, under the alkaline conditions necessary for the dye-fiber reaction, hydroxide ions of water also react with the reactive group of the dye in much the same manner as the cellulosate ion. This produces the hydrolyzed dye, which is incapable of reaction with the fiber ${ }^{[5,6]}$. Hydrolysis of the dye is slower than the reaction with the alkaline cotton but it is significant and reduces the efficiency of the fixation process ${ }^{[7]}$. In case of deep shade, it requires higher amount of alkali for higher $\mathrm{pH}$ to increase exhaustion and fixation which is done by using soda ash only ${ }^{[8]}$. But if mixed alkali (soda ash and caustic soda) is used instead of soda ash or caustic soda only then it shows higher exhaustion and fixation results less hydrolysis of dye reduce less amounts of dye for required shade and improve the fastness properties and overall dyeing performance of reactive dye ${ }^{[9]}$.

\section{Experimental}

Single jersey (Scoured, Bleached and Enzyme) fabrics were cut in rectangular weighing $5 \mathrm{gm}$. The samples were marked by numbering to distinguish each others. The chemicals used as Sandoclean PCLF- (Detergent), Centafoam SC (Anti-foaming agent), Sirrix 2UD(Sequestering agent), Leveling Agent (Drimazin E2R), Electrolyte (Common Salt), Sodium Carbonate (Soda ash, $\mathrm{Na}_{2} \mathrm{CO}_{3}$ ), Caustic Soda $(\mathrm{NaOH})$, Weak acid (acetic acid), Sandoper Sp- RSK. (Soaping agent) and Sandofix EC-(Fixing agent) were laboratory grades. Dye NOVACRON SUPER BLACK G was collected from Huntsman and COTTOFIX BLACK B from Orient Chemtex.

\subsection{Dyeing procedure}

The dyeing was performed in COPOWER sample dyeing machine made by Copower Technology Co. Ltd. Taiwan model no: SUPERMAT V which consists of 24 stainless steel pot running $55 \mathrm{rpm}$ and fully electric heating system with 1:7 liquor ratio. In this experiments dye exhaustion and fixation was conducted with the addition various amount of alkali by the combination of $\mathrm{Na}_{2} \mathrm{Co}_{3}$ and $\mathrm{NaOH}$. All auxiliaries and dyes have been taken in the dye bath with water to maintain 1:7 liquor ratios from the stock solution at room temperature and dyeing was performed by the following process diagram

\subsection{After treatment}

Removal of hydrolyzed and unreacted dye from the goods is a vital step after dyeing. The amount of unfixed dye remaining in a cotton fabric dyed with reactive dyes may have to be less than $0.002 \%$ (owf) ${ }^{[3]}$. To remove unfixed dye the fabric was washed in hot water and neutralization was done through acid wash to remove unfixed dye properly.

*Corresponding Author: Muhammad Abdur Rahman Bhuiyan

E-mail: te_shahid@yahoo.com 


\subsection{Recipe for Dyeing}

Table 1: Recipes for various samples with various amounts of soda ash and alkali

\begin{tabular}{|c|c|c|c|c|c|}
\hline \multirow{2}{*}{ Shade } & $\begin{array}{c}\text { Mill } \\
\text { practice }\end{array}$ & Sample-A & Sample-B & Sample-C & Sample-D \\
\hline \multirow{2}{*}{$8.0 \%$} & $20 \mathrm{~g} / \mathrm{l}$ & $10 \mathrm{~g} / \mathrm{l} \mathrm{Na} \mathrm{Co}_{3}+0.72 \mathrm{~g} / \mathrm{l}$ & $5 \mathrm{~g} / \mathrm{l} \mathrm{Na} \mathrm{Co}_{3}+1.43 \mathrm{~g} / \mathrm{l}$ & $5 \mathrm{~g} / \mathrm{l} \mathrm{Na} \mathrm{Co}_{3}+2.15 \mathrm{~g} / \mathrm{l}$ & $2.86 \mathrm{~g} / \mathrm{l}$ \\
& $\mathrm{Na}_{2} \mathrm{Co}_{3}$ & $\mathrm{NaOH}^{2}$ & $\mathrm{NaOH}$ & $\mathrm{NaOH}$ \\
\hline \multirow{2}{*}{$7.6 \%$} & $20 \mathrm{~g} / \mathrm{l}$ & $10 \mathrm{~g} / \mathrm{l} \mathrm{Na} \mathrm{No}_{3}+0.72 \mathrm{~g} / \mathrm{l}$ & $5 \mathrm{~g} / \mathrm{l} \mathrm{Na} \mathrm{Co}_{3}+1.43 \mathrm{~g} / \mathrm{l}$ & $5 \mathrm{~g} / \mathrm{l} \mathrm{Na} \mathrm{Co}_{3}+2.15 \mathrm{~g} / \mathrm{l}$ & $2.86 \mathrm{~g} / \mathrm{l}$ \\
& $\mathrm{Na}_{2} \mathrm{Co}_{3}$ & $\mathrm{NaOH}^{2}$ & $\mathrm{NaOH}$ & $\mathrm{NaOH}$ \\
\hline \multirow{2}{*}{$7.2 \%$} & $20 \mathrm{~g} / \mathrm{l}$ & $10 \mathrm{~g} / \mathrm{l} \mathrm{Na} \mathrm{No}_{3}+0.72 \mathrm{~g} / \mathrm{l}$ & $5 \mathrm{~g} / \mathrm{l} \mathrm{Na} \mathrm{Co}_{3}+1.43 \mathrm{~g} / \mathrm{l}$ & $5 \mathrm{~g} / \mathrm{l} \mathrm{Na} \mathrm{Co}_{3}+2.15 \mathrm{~g} / \mathrm{l}$ & $2.86 \mathrm{~g} / \mathrm{l}$ \\
& $\mathrm{Na}_{2} \mathrm{Co}_{3}$ & $\mathrm{NaOH}$ & $\mathrm{NaOH}$ & $\mathrm{NaOH}$ & $\mathrm{NaOH}$ \\
\hline
\end{tabular}

Sequestering agent $1.0 \mathrm{~g} / \mathrm{L}$, Wetting Agent $1.0 \mathrm{~g} / \mathrm{L}$, Leveling Agent $1.0 \mathrm{~g} / \mathrm{L}$, Anti creasing agent $0.5 \mathrm{~g} / \mathrm{l}$, salt 80 g/l were used for all experiment

The excess water in the sample was removed by squeezing and dried in the CARBOILITE oven dryer and the drying temperature was $100^{\circ} \mathrm{C}$ for 20 minutes. Calendaring was done at a temperature $150^{\circ} \mathrm{C}$ for few minute to make smooth surface of the fabric.

\section{Results \& Discussions}

Mixed alkali (caustic soda and soda ash) was used as exhausting \& fixing agent to dye the cotton fabric for deep shade with two reactive dyes (Novacron Super Black G) and (Cottofix Black B). Comparative results of different fastness (rubbing and washing) were investigated after dyeing the cotton knit fabrics using soda ash and mixed alkali.

\subsection{Comparison of color fastness to rubbing using mill practice and mixed alkali recipes}

The rubbing fastness (dry and wet rub) of dyed cotton fabrics were examined in ISO $105 \times$ X 12: 1993 [9] methods by crock meter. The change of color of dyed fabrics and rubbing cloth were assessed with the staining Grey scale and rate from 1 (poor) to 5 (excellent). This visual assessment was done in a color matching cabinet under standard lighting D65 (Artificial Daylight). The comparative results are shown in the table 1 and 2 ,

Table $2 \& 3$ show that the fastness test to rubbing (dry and wet rub) of samples (sample A, B, C) that has been dyed with Novacron Super Black G and Cottofix Black B in the presence of mixed alkali and caustic soda are nearly comparable with formal recipe from very good to excellent. In case of wet rubbing, fastness is increasing slightly for the samples A, B, C and D. It is clear that reactive dyes gives better wet rubbing fastness on cotton fabric samples. The fastness improvement may be as a result of better dye penetration and thus good covalent fixation with cotton fabrics.

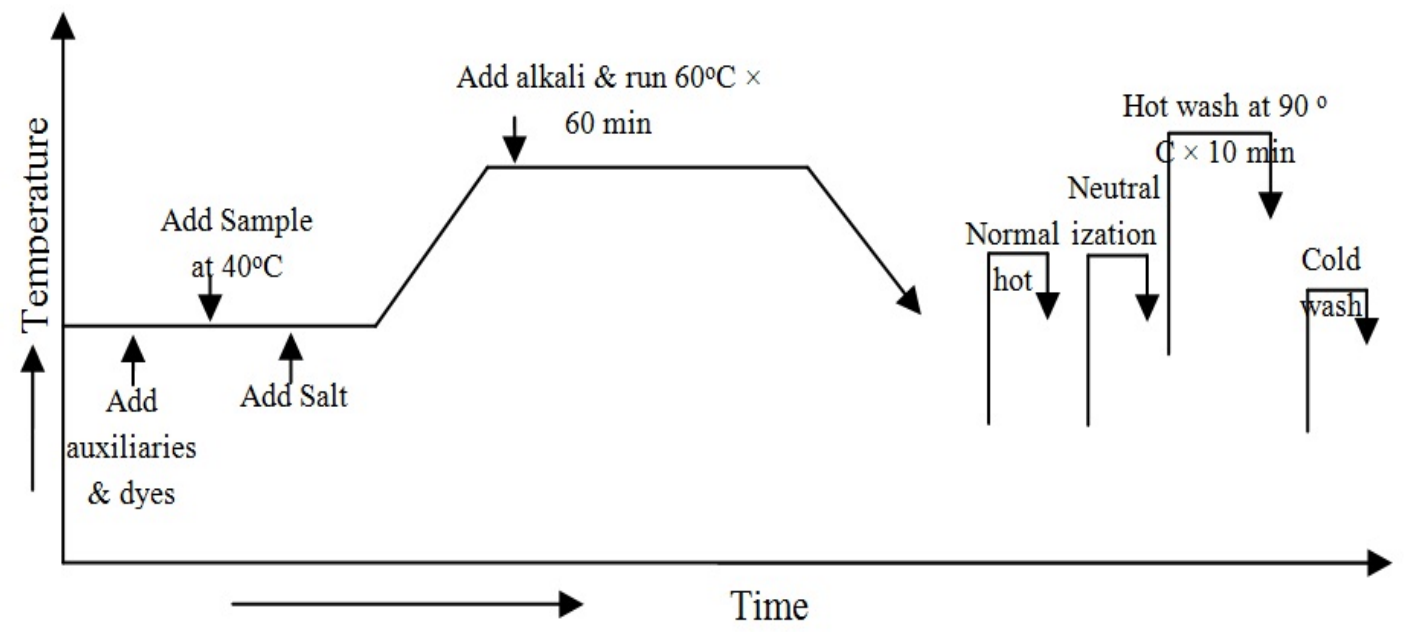

Figure 1: Dyeing curve 
Table 2: Comparison of Color Fastness to Rubbing using mill practice and mixed alkali recipes of Novacron Super Black G

\begin{tabular}{|c|c|c|c|c|c|}
\hline \multirow{3}{*}{ Sample } & \multicolumn{5}{|c|}{ Test Result } \\
\hline & \multirow{2}{*}{$\begin{array}{c}\text { Shade } \\
\%\end{array}$} & \multirow{2}{*}{ Dry } & \multirow{2}{*}{ Wet } & \multicolumn{2}{|c|}{ Cloth view } \\
\hline & & & & Dry & Wet \\
\hline \multirow{3}{*}{$\begin{array}{c}\text { Mill } \\
\text { practice }\end{array}$} & $8.0 \%$ & 4 & 2 & & \\
\hline & $7.6 \%$ & $4-5$ & 2 & & \\
\hline & $7.2 \%$ & 4 & 2 & & \\
\hline \multirow{3}{*}{$\begin{array}{c}\text { Sample- } \\
\text { A }\end{array}$} & $8.0 \%$ & 4 & $2-3$ & & \\
\hline & $7.6 \%$ & 4 & $2-3$ & & \\
\hline & $7.2 \%$ & 4 & 3 & & \\
\hline \multirow{3}{*}{$\begin{array}{c}\text { Sample- } \\
\text { B }\end{array}$} & $8.0 \%$ & 4 & $2-3$ & & \\
\hline & $7.6 \%$ & $4-5$ & 3 & & \\
\hline & $7.2 \%$ & 4 & 3 & & \\
\hline \multirow{3}{*}{$\begin{array}{c}\text { Sample- } \\
\text { C }\end{array}$} & $8.0 \%$ & 4 & $2-3$ & & \\
\hline & $7.6 \%$ & 4-5 & $2-3$ & & \\
\hline & $7.2 \%$ & 4 & 3 & & \\
\hline \multirow{3}{*}{$\begin{array}{c}\text { Sample- } \\
\text { D }\end{array}$} & $8.0 \%$ & 4 & $2-3$ & & \\
\hline & $7.6 \%$ & $4-5$ & 3 & & \\
\hline & $7.2 \%$ & 4 & 3 & & \\
\hline
\end{tabular}

Table 3: Comparison of Color Fastness to Rubbing using mill practice and mixed alkali recipes of COTTOFIX BLACK B dyes

\begin{tabular}{|c|c|c|c|c|c|}
\hline \multirow{3}{*}{ Sample } & \multirow{3}{*}{$\begin{array}{l}\text { Shad } \\
\mathrm{e} \%\end{array}$} & \multicolumn{4}{|c|}{ Test Result } \\
\hline & & \multirow{2}{*}{ Dry } & \multirow{2}{*}{ Wet } & \multicolumn{2}{|c|}{ Cloth view } \\
\hline & & & & Dry & Wet \\
\hline \multirow{3}{*}{$\begin{array}{c}\text { Mill } \\
\text { practice }\end{array}$} & $8.0 \%$ & 4 & $2-3$ & & \\
\hline & $7.6 \%$ & 4 & 2 & & \\
\hline & $7.2 \%$ & 4 & 2 & & \\
\hline \multirow{3}{*}{$\begin{array}{c}\text { Sample- } \\
\text { A }\end{array}$} & $8.0 \%$ & 4 & 3 & & \\
\hline & $7.6 \%$ & $4-5$ & 3 & & \\
\hline & $7.2 \%$ & $4-5$ & 3 & & \\
\hline \multirow{3}{*}{$\begin{array}{c}\text { Sample- } \\
\text { B }\end{array}$} & $8.0 \%$ & 4 & 3 & & \\
\hline & $7.6 \%$ & $4-5$ & 3 & & \\
\hline & $7.2 \%$ & 4 & 3 & & \\
\hline \multirow{3}{*}{$\begin{array}{c}\text { Sample- } \\
\text { C }\end{array}$} & $8.0 \%$ & 4 & 3 & & \\
\hline & $7.6 \%$ & 4 & 3 & & \\
\hline & $7.2 \%$ & 4 & 3 & & \\
\hline \multirow{3}{*}{$\begin{array}{c}\text { Sample- } \\
\text { D }\end{array}$} & $8.0 \%$ & $4-5$ & 3 & & \\
\hline & $7.6 \%$ & 4 & 3 & & \\
\hline & $7.2 \%$ & 4 & 3 & & \\
\hline
\end{tabular}


Table 4: Color fastnesses to Washing of NOVACRON SUPER BLACK G dyes

\begin{tabular}{|c|c|c|c|c|c|}
\hline \multirow[t]{3}{*}{ Sample } & \multicolumn{5}{|c|}{ Test Result } \\
\hline & \multirow{2}{*}{$\begin{array}{c}\text { Staining } \\
\text { in }\end{array}$} & \multicolumn{4}{|c|}{ Grade } \\
\hline & & grade & $8.0 \%$ & $\begin{array}{c}7.6 \\
\%\end{array}$ & $\begin{array}{c}7.2 \\
\%\end{array}$ \\
\hline \multirow{6}{*}{$\begin{array}{c}\text { Mill } \\
\text { practice }\end{array}$} & Acetate & $4-5$ & & & \\
\hline & Cotton & $4-5$ & & & \\
\hline & Nylon & $4-5$ & & & \\
\hline & Polyester & $4-5$ & & & \\
\hline & Acrylic & $4-5$ & & & \\
\hline & Wool & $4-5$ & & & \\
\hline \multirow{6}{*}{ Sample-A } & Acetate & $4-5$ & & & \\
\hline & Cotton & $4-5$ & & & \\
\hline & Nylon & $4-5$ & & & \\
\hline & Polyester & $4-5$ & & & \\
\hline & Acrylic & $4-5$ & & & \\
\hline & Wool & $4-5$ & & & \\
\hline \multirow{6}{*}{ Sample-B } & Acetate & $4-5$ & & & \\
\hline & Cotton & $4-5$ & & & \\
\hline & Nylon & $4-5$ & & & \\
\hline & Polyester & $4-5$ & & & \\
\hline & Acrylic & $4-5$ & & & \\
\hline & Wool & $4-5$ & & & \\
\hline \multirow{6}{*}{ Sample-C } & Acetate & $4-5$ & & & \\
\hline & Cotton & $4-5$ & & & \\
\hline & Nylon & $4-5$ & & & \\
\hline & Polyester & $4-5$ & & & \\
\hline & Acrylic & $4-5$ & & & \\
\hline & Wool & $4-5$ & & & \\
\hline \multirow{6}{*}{ Sample-D } & Acetate & $4-5$ & & & \\
\hline & Cotton & $4-5$ & & & \\
\hline & Nylon & $4-5$ & & & \\
\hline & Polyester & $4-5$ & & & \\
\hline & Acrylic & $4-5$ & & & \\
\hline & Wool & $4-5$ & & & \\
\hline
\end{tabular}

Table 5: Color fastnesses to Washing of COTTOFIX BLACK B dyes

\begin{tabular}{|c|c|c|c|c|c|}
\hline \multirow[t]{3}{*}{ Sample } & \multicolumn{5}{|c|}{ Test Result } \\
\hline & \multirow{2}{*}{$\begin{array}{l}\text { Staining } \\
\text { in }\end{array}$} & \multicolumn{4}{|c|}{ Grade } \\
\hline & & Grade & $8.0 \%$ & $\begin{array}{c}7.6 \\
\%\end{array}$ & $\begin{array}{c}7.2 \\
\%\end{array}$ \\
\hline \multirow{6}{*}{$\begin{array}{c}\text { Mill } \\
\text { practice }\end{array}$} & Acetate & $4-5$ & & & \\
\hline & Cotton & $4-5$ & & & \\
\hline & Nylon & $4-5$ & & & \\
\hline & Polyester & $4-5$ & & & \\
\hline & Acrylic & $4-5$ & & & \\
\hline & Wool & $4-5$ & & & \\
\hline \multirow{6}{*}{$\begin{array}{c}\text { Sample- } \\
\text { A }\end{array}$} & Acetate & $4-5$ & & & \\
\hline & Cotton & $4-5$ & & & \\
\hline & Nylon & $4-5$ & & & \\
\hline & Polyester & $4-5$ & & & \\
\hline & Acrylic & $4-5$ & & & \\
\hline & Wool & $4-5$ & & & \\
\hline \multirow{6}{*}{$\begin{array}{c}\text { Sample- } \\
\text { B }\end{array}$} & Acetate & $4-5$ & & & \\
\hline & Cotton & $4-5$ & & & \\
\hline & Nylon & $4-5$ & & & \\
\hline & Polyester & $4-5$ & & & \\
\hline & Acrylic & $4-5$ & & & \\
\hline & Wool & $4-5$ & & & \\
\hline \multirow{6}{*}{$\begin{array}{c}\text { Sample- } \\
\text { C }\end{array}$} & Acetate & $4-5$ & & & \\
\hline & Cotton & $4-5$ & & & \\
\hline & Nylon & $4-5$ & & & \\
\hline & Polyester & $4-5$ & & & \\
\hline & Acrylic & $4-5$ & & & \\
\hline & Wool & $4-5$ & & & \\
\hline \multirow{6}{*}{$\begin{array}{c}\text { Sample- } \\
\text { D }\end{array}$} & Acetate & $4-5$ & & & \\
\hline & Cotton & $4-5$ & & & \\
\hline & Nylon & $4-5$ & & & \\
\hline & Polyester & $4-5$ & & & \\
\hline & Acrylic & $4-5$ & & & \\
\hline & Wool & $4-5$ & & & \\
\hline
\end{tabular}




\subsection{Comparison of color fastness to washing using mill practice and mixed alkali recipes}

The color fastness to washing is measured by ISO Recommendation No. 1 (ISO 105 C01) ${ }^{[9]}$. A rating of 1 (poor) -5 (excellent) was assigned to each of the six fiber strips on the fabric. Each of these test would carried out at 50:1 liquor ratio in a 2.0 liter wash wheel vessel with $5.0 \mathrm{~g} / \mathrm{l}$ standard soap solution. Cross staining of a third party fabric is assessed using an adjacent fabric fixed to the fabric test sample. Adjacent fabrics come in many types and many forms including cotton, wool, polyamide, acrylic, acetate and polyester. Evaluation of the wash fastness is established using the Grey- Scale for the change in color for dyed samples and staining for adjacent multi-fiber fabrics.

\subsection{Color difference measurement of trial sample (dyeing with mixed alkali) from the mill practice sample (dyeing with soda ash only)}

Under the light box (Verivide light box made by England) all samples which are prepared by the different concentration of alkali used to fixing system are matching each to others. The Illuminant D65 is used to matching the shade. Which samples are similar depth of shade to the observer those have sent to make CMC report to compare difference of shade each to others. The CMC reports are taken from X-rite SCOPESupreme Color Physics Expert, Model: Color Eye 7000A.

Color difference measurement of trial sample from the mill practice of NOVACRON SUPER BLACK G dyes:

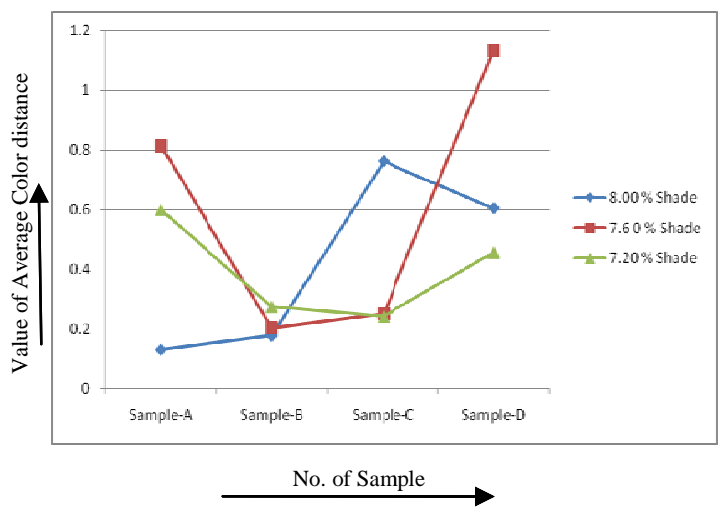

Figure 2: Graphical presentation of CMC report of Novacron dyes

The more acceptable Sample is 7.2\% Shade (SampleA). The color difference from the Standard Sample (Shade $8.0 \%$ \& without caustic) is 0.242 .
Color difference measurement of trial sample from the mill practice for COTTOFIX BALCK B dyes:

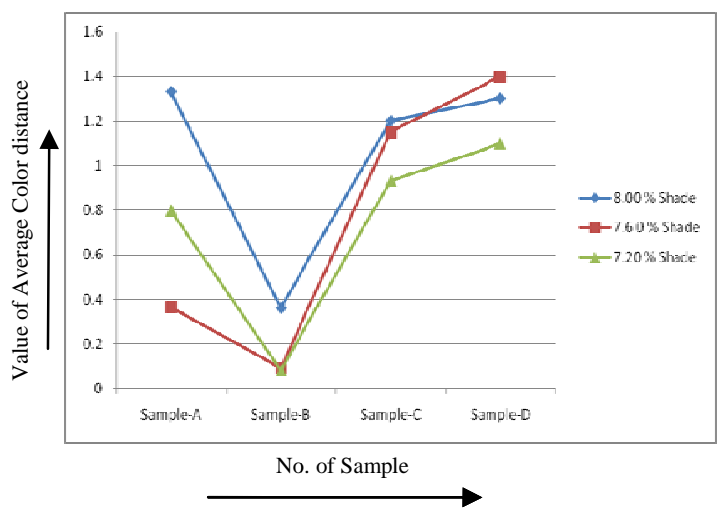

Figure 3: Graphical presentation of CMC report of Cottofix Black B dye

Here, the more acceptable Sample is $7.2 \%$ Shade (Sample-B). The color difference from the Standard Sample (Shade $8.0 \%$ \& without caustic) is 0.081 .

\section{Conclusion}

This study explores the viability of replacing the soda ash (sodium carbonate) by mixed alkali (sodium carbonate and sodium hydroxide) as fixing agent agents, which is widely used in the dyeing of cotton fabric with reactive dyes for deep shade. By using the proper amount of caustic soda with soda ash as a mixed alkali than the fastness properties are shown very good to excellent and the process cost also reduced due high fixation and less hydrolysis of dye molecule on the fixation process during dyeing. The overall performances of dyeing with mixed alkali found in the experiment are given;

- Using up to $1.5 \%$ (owf) or $2.15 \mathrm{gm} / \mathrm{l}$ caustic soda with $5 \mathrm{gm} / \mathrm{l}$ soda ash as a mixed alkali reduce $10 \%$ dyestuff from its original shade\% to get same depth of color in case of Novacron Super Black G.

- Using up to $1.0 \%$ (owf) or $1.43 \mathrm{gm} / \mathrm{l}$ caustic soda with $5 \mathrm{gm} / \mathrm{l}$ soda ash as a mixed alkali reduce 10\% dyestuff from its original shade to get the same depth of color in case of Cottofix Black B.

- The mixed alkali fixation process of Reactive dyes for deep shade is more economical with respect to mild alkali fixation process.

- Fastness properties are improved for the same depth of shade and dyeing cost is reduced due to using less quantity of dyes, soda ash and salt 


\section{References}

1. Iqbal, M., Textile Dyes, Rehbar publishers, Karachi, 63, 2008.

2. Shore, J., Cellulosics Dyeing, Society of Dyers and Colorists, 199, 1995.

3. Broadbent, A. D., Basic Principles of Textile Coloration, Society of dyers and Colorists, 332344, 2001.

4. Park, J. and Shore, J., Practical Dyeing (Vol. 2), Society of Dyers and Colourists, 70-75, 2004.

5. Rastar, A., and Hoseinpour, A., Simultaneous Dyeing and Bleaching of Cotton Materials World Applied Sciences Journal 14 (8): 1186-1189, 2011

6. Vassileva, E. V., The Kinetic Model of Reactive Dye Fixation on Cotton Fibres, Journal of the
University of Chemical Technology and Metallurgy, 43(3): 323-326, 2008.

7. Tomasino, D. C., Chemistry \& Technology of Fabric Preparation and Finishing. Raleigh, North Carolina State University, North Carolina, 31-40, 1992.

8. Wei, MA., Shu-fen, Z. and Jin-zong, Y., Development of functional polymers in modification of cotton for improving dye ability of reactive dyes, The Proceedings of the $3 r d$ International Conference on Functional Molecules, State key Laboratory of Dalian University of Technology, China-116012, 2005.

9. Lewis D M, Lei X P, New methods for improving the dye ability of cellulose fibers with reactive dyes, J. Soc. Dyers Colour., 107: 102, 1991. 